\title{
AKIBAT HUKUM PENITIPAN GANTI KERUGIAN UANG DI PENGADILAN NEGERI DALAM PENGADAAN TANAH UNTUK KEPENTINGAN UMUM TERHADAP HAK ATAS TANAH
}

\author{
Dr. Suyanto \\ Dosen \& Dekan Fakultas Hukum Universitas Gresik, Jl. AR. Hakim No.2B, Gresik \\ * E-mail korespondensi: soe.unigres@gmail.com
}

\begin{abstract}
ABSTRAK
Pasal 43 Undang-Undang No. 2 Tahun 2012 menetapkan bahwa dengan penitipan ganti kerugian uang di Pengadilan Negeri dalam pengadaan tanah untuk kepentingan umum berakibat alat bukti hak atas tanah (sertipikat hak) dinyatakan tidak berlaku. Tidak berlakunya alat bukti hak atas tanah (sertipikat hak) sebagai akibat hukum dari penitipan ganti kerugian di Pengadilan Negeri bertentangan dengan asas contrarius actus, yaitu Pengadilan Negeri tidak berwenang membatalkan sertipikat hak. Pejabat yang berwenang membatalkan sertipikat hak adalah Kepala Badan Pertanahan Nasional Republik Indonesia. Akibat hukum penitipan ganti kerugian di Pengadilan Negeri adalah hak atas tanah menjadi hapus, dan tanahnya kembali menjadi tanah negara merupakan pengambilan tanah hak secara paksa oleh Pelaksana Pengadaan Tanah dengan dalih untuk kepentingan umum. Perolehan tanah dalam pengadaan tanah untuk kepentingan umum dengan cara menitipkan ganti kerugian di Pengadilan Negeri dapat disamakan dengan pencabutan hak atas tanah disebabkan pihak yang berhak tidak punya pilihan lain, kecuali harus menerima besarnya ganti kerugian yang ditetapkan oleh Ketua Pelaksana Pengadaan Tanah.
\end{abstract}

Kata Kunci: Penitipan, ganti kerugian, Hak atas tanah.

\section{ABSTRACT}

Article 43 of Law No. 2 of 2012 stipulates that with the safekeeping of compensation for money in the District Court in the procurement of land for public interest resulting in an instrument of proof of land rights (certificate of rights) declared invalid. The non-entry into force of proof of land rights (certificate of rights) as a result of the legal safekeeping of compensation in the District Court is contrary to the principle of contrarius actus, namely the District Court is not authorized to cancel the certificate of rights. The official who has the authority to cancel the certificate of rights is the Head of the National Land Agency of the Republic of Indonesia. The legal consequences of indemnity safeguards in the District Court are the right to land to be abolished, and the land returned to state land as a forced land acquisition by the Land Procurement Executor under the pretext of public interest. Land acquisition in the procurement of land for the public interest by depositing compensation in the District Court can be equated with the revocation of land rights because the rightful party has no other choice, except having to accept the amount of compensation determined by the Chairperson of Land Procurement.

Keywords: Compensation, Deposit, Land rights.

\section{A. PENDAHULUAN}

Tanah yang dibutuhkan untuk pembangunan nasional dapat berasal dari tanah hak. Cara perolehan hak atas tanah yang berasal dari tanah hak dapat ditempuh melalui 2 (dua) cara, yaitu : a) 
Kalau pemegang hak atas tanah bersedia melepaskan hak atas tanahnya, maka cara perolehan tanahnya ditempuh melalui pemindahan hak atas tanah, atau pelepasan hak atas tanah oleh pemegang haknya; b) Kalau pemegang hak atas tanah tidak bersedia melepaskan hak atas tanahnya dan tanahnya diperlukan untuk kepentingan umum, maka cara perolehan tanahnya ditempuh melalui pencabutan hak atas tanah (Santoso, 2013).

Perolehan hak atas tanah yang berasal dari tanah hak untuk memenuhi kebutuhan pembangunan nasional pada hakekatnya adalah pengambilan tanah hak. Abdurrahman (1996) menyatakan bahwa berkenaan dengan pengambilan tanah-tanah penduduk yang akan dipakai untuk keperluan pembangunan menurut ketentuan hukum yang berlaku dapat dilakukan melalui 2 (dua) cara, yaitu : a) Pembebasan tanah (prijsgeving). Pembebasan tanah ialah melepaskan hubungan hukum semula yang terdapat di antara pemegang hak/penguasa atas tanah dengan cara pemberian ganti rugi atas dasar musyawarah dengan pihak yang bersangkutan; b) Pencabutan hak atas tanah (onteigening). Pencabutan hak atas tanah ialah pengambilan tanah kepunyaan sesuatu pihak oleh negara secara paksa, yang mengakibatkan hak atas tanah menjadi hapus, tanpa yang bersangkutan melakukan pelanggaran atau lalai dalam melakukan suatu kewajiban hukum.

Untuk memperoleh tanah guna kepentingan pembangunan dapat ditempuh melalui pengadaan tanah. Sebelum berlakunya pengadaan tanah, perolehan tanah untuk kepentingan pembangunan diberlakukan pembebasan tanah yang diatur dalam Peraturan Menteri Dalam Negeri No. 15 Tahun 1975 tentang Ketentuan-ketentuan Mengenai Tata Cara Pembebasan Tanah. Perolehan tanah untuk kepentingan pembangunan melalui pembebasan tanah diganti melalui pengadaan tanah yang diatur dalam Keputusan Presiden Republik Indonesia No. 55 Tahun 1993 tentang Pengadaan Tanah Bagi Pelaksanaan Pembangunan Untuk Kepentingan Umum.

Pengertian pengadaan tanah dinyatakan dalam Pasal 1 angka 2 Undang-Undang 
No. 2 Tahun 2012 juncto Pasal 1 angka 2 Peraturan Presiden RI No. 71 Tahun 2012 sebagaimana diubah yang keempat oleh Pasal 1 angka 2 Peraturan Presiden RI No. 148 Tahun 2015, yaitu kegiatan menyediakan tanah dengan cara memberikan ganti kerugian yang layak dan adil kepada pihak yang berhak. Maria S.W. Sumardjono (2015) memberikan pengertian pengadaan tanah yaitu setiap kegiatan mendapatkan tanah dengan cara memberikan ganti kerugian kepada yang berhak atas tanah. Pengertian pengadaan tanah untuk kepentingan umum adalah kegiatan menyediakan tanah untuk kepentingan umum oleh instansi yang memerlukan tanah sesuai dan berdasar kepada Rencana Tata Ruang Wilayah (RTRW) yang telah ditetapkan dengan cara memberikan ganti kerugian yang layak dan adil kepada pihak yang berhak atas tanah, bangunan, tanaman, dan/atau benda-benda lain yang berkaitan dengan tanah (Santoso, 2018).

Pengadaan tanah untuk kepentingan umum dilaksanakan melalui 4 (empat) tahapan, yaitu perencanaan, persiapan, pelaksanaan, dan penyerahan hasil. Pengadaan tanah untuk kepentingan umum dilaksanakan oleh Pelaksana Pengadaan Tanah (PPT) yang dibentuk oleh Kepala Badan Pertanahan Nasional Republik Indonesia. Ketua Pelaksana Pengadaan Tanah (PPT) adalah Kepala Kantor Wilayah Badan Pertanahan Nasional Provinsi. Dalam pelaksanaan pengadaan tanah untuk kepentingan umum, Kepala Kantor Wilayah Badan Pertanahan Nasional Provinsi dapat melimpahkan kewenangannya kepada Kepala Kantor Pertanahan Kabupaten/Kota sebagai Ketua Pelaksana Pengadaan Tanah (PPT).

Perolehan tanah dalam pelaksanaan pengadaan tanah untuk kepentingan umum ditempuh melalui pelepasan hak oleh pihak yang berhak atas ganti kerugian. Pengertian pelepasan hak dinyatakan dalam Pasal 1 angka 9 Undang-Undang No. 2 Tahun 2012 juncto Pasal 1 angka 9 Peraturan Presiden RI No. 71 Tahun 2012 sebagaimana diubah yang keempat oleh Pasal 1 angka 9 Peraturan Presiden RI No. 148 Tahun 2015, adalah 
kegiatan pemutusan hubungan hukum dari pihak yang berhak kepada negara melalui Lembaga Pertanahan (Badan Pertanahan Nasional Republik Indonesia).

Tujuan penelitian ini adalah untuk: 1) menganalisis dan menemukan ketidakberlakuan sertipikat hak atas tanah sebagai akibat penitipan ganti kerugian uang di Pengadilan Negeri dalam pengadaan tanah untuk kepentingan umum, 2) menganalisis dan menemukan hapusnya hak atas tanah sebagai akibat penitipan ganti kerugian uang di Pengadilan Negeri dalam pengadaan tanah untuk kepentingan umum.

\section{B. METODE PENELITIAN}

Jenis penelitian ini merupakan penelitian yuridis normatif yang mengkaji secara kritis dan komprehensif akibat hukum penitipan ganti kerugian uang dalam pengadaan tanah untuk kepentingan umum terhadap hak atas tanah. Titik berat penelitian yuridis normatif, sesuai dengan karakter keilmuan hukum yang khas, terletak pada telaah hukum atau kajian hukum terhadap hukum positif, yang meliputi tiga lapisan keilmuan hukum, terdiri atas telaah dogmatika hukum, teori hukum, dan filsafat hukum. Pada tataran dogmatika hukum, pengkajiannya dilakukan terhadap identifikasi dalam hukum positif, khususnya Undang-Undang. Sedangkan pada tataran teori hukum dilakukan telaah terhadap teori-teori yang dapat digunakan.

Untuk memahami hubungan antara ilmu hukum dengan hukum positif dalam hal ini adalah hukum tertulis, oleh karena menyangkut penelitian hukum normatif diperlukan suatu telaah terhadap unsur hukum atau gegevensvan het recht. Unsur-unsur hukum tersebut mencakup unsur ideal dan unsur riel. Unsur ideal tersebut mencakup hasrat sosial dan rasio manusia. Hasrat manusia tersebut menghasilkan asas-asas hukum (rechtsbeginselen), sedangkan unsur riel mencakup manusia, kebudayaan, dan lingkungan alam yang menghasilkan tata hukum (Mamuji, 1990).

Unsur ideal menghasilkan norma hukum melalui filsafat hukum dan normwissenschaft. Dalam hal ini, 
penelitian terhadap asas hukum mungkin bertitik tolak dari bidang-bidang tata hukum yang tertulis dan tertentu, dengan cara mengadakan identifikasi terlebih dulu terhadap norma-norma hukum yang dirumuskan di dalam peraturan perundang-undangan tertentu (Noorhadi, 2005). Penelitian ini dilakukan terhadap peraturan perundang-undangan dan selanjutnya dirumuskan norma hukumnya dan barulah ditarik asasnya.

Dalam penelitian ini menggunakan bahan hukum primer dan sekunder. Bahan hukum primer yang berkaitan adalah undang-undang, peraturan Presiden Republik Indonesia, peraturan kepala badan pertanahan nasional, peraturan menteri agraria dan tata ruang atau kepada badan pertanahan nasional. Bahan hukum sekunder, yaitu bahan hukum yang memberikan penjelasan mengenai bahan hukum primer, seperti studi kepustakaan dan studi dokumentasi, arsip, data resmi pemerintah, buku-buku hukum, makalah hukum, jurnal hukum, majalah hukum, dan hasil penelitian terdahulu yang berkaitan dengan penelitian ini.
Analisis bahan hukum dilakukan dengan terlebih dulu mengidentifikasi bahan hukum yang terkumpul, kemudian didiskripsikan, disistematisasikan dengan mendasarkan pada teori keilmuan hukum dan konsep-konsep ilmu hukum, prinsip atau asas hukum. Selanjutnya, analisis bahan hukum yang dipergunakan dalam penelitian disertasi ini adalah analisis yuridis kualitatif, yaitu analisis yang mendasarkan atau bertumpu pada penalaran hukum (legal reasoning), intepretasi hukum (legal intepretation), dan argumentasi hukum (legal argumentation) secara runtut. Penggunaan analisis bahan hukum yang demikian, diharapkan dapat menjelaskan permasalahan dalam penelitian ini.

\section{HASIL DAN PEMBAHASAN}

1. Ketidakberlakuan Sertipikat Hak Atas Tanah Sebagai Akibat Penitipan Ganti Kerugian Uang di Pengadilan Negeri dalam Pengadaan Tanah Untuk Kepentingan Umum

Alat bukti hak atas tanah yang berupa sertipikat hak atas tanah merupakan hasil dari pendaftaran tanah yang diatur dalam 
Undang-Undang No. 5 Tahun 1960 (UUPA) dan Peraturan Pemerintah No. 24

Tahun 1997 tentang Pendaftaran Tanah. Salah satu tujuan pembuatan undang-undang dan peraturan tersebut adalah meletakkan dasar-dasar untuk memberikan kepastian hukum mengenai hak-hak atas tanah bagi rakyat seluruhnya. Untuk mewujudkan tujuan memberikan jaminan kepastian hukum mengenai hak-hak atas tanah dapat dilakukan melalui pendaftaran tanah atas bidang-bidang tanah di seluruh wilayah Republik Indonesia.

Pasal 19 ayat (1) Undang-Undang No. 5 Tahun 1960 (UUPA) menetapkan bahwa yang berkewajiban mengadakan pendaftaran tanah adalah Pemerintah. Hak Milik (Pasal 23 Undang-Undang No. 5 Tahun 1960 (UUPA), Hak Guna Usaha (Pasal 32 Undang-Undang No. 5 Tahun 1960 (UUPA), Hak Guna Bangunan (Pasal 38 Undang-Undang No. 5 Tahun 1960 (UUPA)) wajib didaftar oleh pemegang haknya. Dengan demikian pihak yang berkewajiban mengadakan pendaftaran tanah adalah Pemerintah (Badan
Pertanahan Nasional RI) dan pemegang hak atas tanah.

Pengertian pendaftaran tanah dinyatakan dalam Pasal 1 angka 1 Peraturan Pemerintah No. 24 Tahun 1997, yaitu serangkaian kegiatan yang dilakukan oleh Pemerintah secara terus menerus, berkesinambungan, dan teratur, meliputi pengumpulan, pengolahan, pembukuan, dan penyajian serta pemeliharaan data fisik dan data yuridis, dalam bentuk peta dan daftar, mengenai bidang-bidang tanah dan satuan-satuan rumah susun, termasuk pemberian surat tanda bukti haknya bagi bidang-bidang tanah yang sudah ada haknya dan hak milik atas satuan rumah susun serta hak-hak tertentu yang membebaninya.

Penerbitan sertipikat sebagai salah satu tujuan pendaftaran tanah ditetapkan dalam Pasal 3 huruf a dan Pasal 4 huruf a Peraturan Pemerintah No. 24 Tahun 1997, yaitu : "Untuk memberikan kepastian hukum dan perlindungan hukum kepada pemegang hak atas suatu bidang tanah, satuan rumah susun dan hak-hak lain yang terdaftar agar dengan mudah dapat 
membuktikan dirinya sebagai pemegang hak yang bersangkutan. Untuk memberikan kepastian hukum dan perlindungan hukum, kepada pemegang hak yang bersangkutan diberikan sertipikat hak atas tanah".

Sertipikat diterbitkan oleh Kantor

Pertanahan Kabupaten/Kota. Sertipikat memuat data fisik dan data yuridis yang merupakan salinan dari Buku Tanah. Pengertian buku tanah dinyatakan dalam Pasal 1 angka 19 Peraturan Pemerintah No. 24 Tahun 1997, yaitu dokumen dalam bentuk daftar yang memuat data yuridis dan data fisik suatu objek pendaftaran tanah yang sudah ada haknya. Sertipikat berfungsi sebagai surat tanda bukti hak yang memuat data fisik dan data yuridis, yang merupakan salinan dari buku tanah. Sertipikat sebagai surat tanda bukti hak mempunyai sifat pembuktian yang kuat, sebagaimana dinyatakan dalam Pasal 19 ayat (2) huruf c Undang-Undang No. 5 Tahun 1960 (UUPA), yaitu pemberian surat-surat tanda bukti hak yang berlaku sebagai alat pembuktian yang kuat (Suyanto \& Arif, 2017).
Dengan diterbitkan sertipikat sebagai surat tanda bukti hak, maka terwujud perlindungan hukum bagi pemilik sertipikat atau pemegang hak atas tanah, yaitu mendapatkan rasa aman, rasa nyaman, dan tidak mendapatkan gangguan atau gugatan dari pihak lain. Perlindungan hukum bagi pemilik sertipikat atau pemegang hak atas tanah dapat terwujud apabila dalam penerbitan sertipikat tidak ada cacat yuridis, yaitu cacat prosedur, cacat substansi, atau cacat kewenangan.

Sehubungan dengan sertipikat merupakan tanda bukti hak yang bersifat kuat, Boedi Harsono (2003) menyatakan bahwa selama tidak dapat dibuktikan sebaliknya, data fisik dan data yuridis yang tercantum dalam sertipikat harus diterima sebagai data yang benar, baik dalam melakukan perbuatan hukum sehari-hari maupun dalam berperkara di pengadilan. Sudah barang tentu data fisik dan data yuridis yang tercantum dalam sertipikat harus sesuai dengan data yang tercantum dalam buku tanah dan surat ukur yang bersangkutan, karena data itu diambil dari buku tanah dan surat ukur tersebut. 
Arti sertipikat sebagai alat pembuktian yang kuat, adalah data fisik dan data yuridis yang dimuat dalam sertipikat dianggap benar sepanjang tidak dibuktikan sebaliknya dengan alat bukti yang lain yang dapat berupa sertipikat atau selain sertipikat. Berdasarkan sifat pembuktian ini, pihak yang merasa dirugikan atas diterbitkan sertipikat dapat mengajukan gugatan ke pengadilan untuk memohon agar sertipikat yang diterbitkan tersebut dinyatakan tidak sah atau batal. Kalau putusan pengadilan mempunyai kekuatan hukum tetap yang memutuskan bahwa sertipikat tersebut tidak sah atau batal, maka Kepala Badan Pertanahan Nasional Republik Indonesia menerbitkan surat keputusan tentang pembatalan sertipikat.

Pasal 43 Undang-Undang No. 2 Tahun 2012 menetapkan bahwa pada saat pelaksanaan pemberian ganti kerugian dan pelepasan hak sebagaimana dimaksud dalam Pasal 41 ayat (2) huruf a telah dilaksanakan atau pemberian ganti kerugian sudah dititipkan di Pengadilan Negeri sebagaimana dimaksud dalam
Pasal 41 ayat (1), kepemilikan atau hak atas tanah dari pihak yang berhak menjadi hapus dan alat bukti haknya dinyatakan tidak berlaku dan tanahnya menjadi tanah yang dikuasai langsung oleh negara.

Berdasarkan ketentuan Pasal 43 Undang-Undang No. 2 Tahun 2012, penitipan ganti kerugian uang di Pengadilan Negeri dalam pengadaan tanah untuk kepentingan umum berakibat alat bukti hak atas tanah dinyatakan tidak berlaku. Dengan penitipan ganti kerugian uang di Pengadilan Negeri dalam pengadaan tanah untuk kepentingan umum, sertipikat hak atas tanah dinyatakan tidak berlaku. Penitipan ganti kerugian uang di Pengadilan Negeri dalam pengadaan tanah untuk kepentingan umum yang dapat disebabkan oleh tidak tercapainya kesepakatan dalam musyawarah mengenai bentuk dan/atau besarnya ganti kerugian antara Pelaksana Pengadaan Tanah (PPT) dan pihak yang berhak, yang berakibat sertipikat hak atas tanah dinyatakan tidak berlaku. Dengan tidak berlakuunya sertipikat hak atas tanah, maka sertipikat hak atas tanah menjadi 
batal atau tidak sah.

Secara teoritik, sertipikat hak atas tanah

dinyatakan batal sehingga tidak berlaku disebabkan oleh : a) Cacat hukum administratif. Pihak yang mengajukan pembatalan hak atas tanah ditetapkan dalam Pasal 106 Peraturan Menteri Negara Agraria/Kepala Badan Pertanahan Nasional No. 9 Tahun 1999, yaitu keputusan pembatalan hak atas tanah karena cacat hukum administratif dalam penerbitannya, dapat dilakukan karena permohonan yang berkepentingan atau oleh pejabat yang berwenang tanpa permohonan. Permohonan pembatalan hak atas tanah dapat diajukan langsung kepada Menteri Agraria dan Tata Ruang/Kepala Badan Pertanahan Nasional Republik Indonesia atau pejabat yang ditunjuk atau melalui Kepala Kantor Pertanahan Kabupaten/Kota. Pasal 105 Peraturan Menteri Negara Agraria/Kepala Badan Pertanahan Nasional No. 9 Tahun 1999 menetapkan pejabat yang berwenang membatalkan hak atas tanah, yaitu pembatalan hak atas tanah dilakukan dengan keputusan yang diterbitkan oleh
Menteri Agraria dan Tata Ruang/Kepala Badan Pertanahan Nasional Republik Indonesia. Kewenangan untuk membatalkan hak atas tanah dapat dilimpahkan kepada Kepala Kantor Wilayah Badan Pertanahan Nasional Provinsi, atau Kepala Kantor Pertanahan Kabupaten/Kota; b) Melaksanakan putusan pengadilan yang telah mempunyai kekuatan hukum tetap. Sertipikat hak atas tanah dapat menjadi objek sengketa tata usaha negara disebabkan sertipikat hak atas tanah merupakan Keputusan Tata Usaha Negara (KTUN). Pengertian sengketa tata usaha negara dinyatakan dalam Pasal 1 angka 4 Undang-Undang No. 5 Tahun 1986 tentang Peradilan Tata Usaha Negara adalah sengketa yang timbul dalam bidang tata usaha negara antara orang atau badan hukum perdata dengan Badan atau Pejabat Tata Usaha Negara, baik di pusat maupun di daerah sebagai akibat dikeluarkannya Keputusan Tata Usaha Negara (KTUN), termasuk sengketa kepegawaian berdasarkan peraturan perundang-undangan yang berlaku. 
Apabila gugatan sengketa penerbitan sertipikat hak atas tanah sebagai sengketa tata usaha negara dikabulkan, maka Pengadilan Tata Usaha Negara menerbitkan putusan bahwa sertipikat hak atas tanah sebagai Keputusan Tata Usaha Negara dinyatakan tidak sah. Apabila putusan Pengadilan Tata Usaha Negara yang telah memperoleh kekuatan hukum tetap, maka dalam rangka melaksanakan putusan Pengadilan Tata Usaha Negara tersebut, Kepala Badan Pertanahan Nasional Republik Indonesia atau pejabat di Badan Pertanahan Nasional Republik Indonesia yang diberikan pelimpahan kewenangan menerbitkan Surat Keputusan tentang pembatalan sertipikat hak atas tanah.

Dengan penitipan ganti kerugian uang oleh instansi yang memerlukan tanah di Pengadilan Negeri dalam pengadaan tanah untuk kepentingan umum berakibat sertipikat hak atas tanah dinyatakan tidak berlaku. Dengan tidak berlakunya sertipikat hak atas tanah tersebut membuat sertipikat menjadi tidak sah, batal, atau sertipikat hak atas tanah tidak lagi menjadi surat tanda bukti hak.

Tidak sah atau batalnya sertipikat hak atas tanah yang disebabkan oleh penitipan ganti kerugian uang oleh instansi yang memerlukan tanah di Pengadilan Negeri dalam pengadaan tanah untuk kepentingan umum tidak memenuhi syarat sahnya keputusan, yaitu ditetapkan oleh bukan pejabat yang berwenang, sebagaimana ditetapkan dalam Pasal 52 Undang-Undang No. 30 Tahun 2014 tentang Administrasi Pemerintahan. Instansi yang memerlukan tanah tidak mempunyai kewenangan untuk membatalkan sertipikat hak atas tanah. Penitipan ganti kerugian uang oleh instansi yang memerlukan tanah di Pengadilan Negeri dalam pengadaan tanah untuk kepentingan umum yang berakibat sertipikat hak atas tanah dinyatakan tidak berlaku bertentangan dengan asas contrarius actus, yaitu Badan atau Pejabat Tata Usaha Negara yang menerbitkan Keputusan Tata Usaha Negara dengan sendirinya juga berwenang untuk membatalkannya (Hadjon \& Djatmiati, 2016). Berdasarkan asas contrarius actus, 
sertipikat hak atas tanah diterbitkan oleh Badan Pertanahan Nasional Republik Indonesia, maka pejabat yang berwenang membatalkan sertipikat hak atas tanah adalah Kepala Badan Pertanahan Nasional Republik Indonesia, atau pejabat di Badan Pertanahan Nasional Republik Indonesia yang diberikan pelimpahan kewenangan. Kalau sertipikat hak atas tanah dinyatakan tidak berlaku (batal) yang disebabkan oleh penitipan ganti kerugian uang oleh instansi yang memerlukan tanah di Pengadilan Negeri dalam pengadaan tanah untuk kepentingan umum, maka batalnya sertipikat hak atas tanah tersebut tidak sah disebabkan dibatalkan oleh bukan pejabat yang berwenang.

\section{Hapusnya Hak Atas Tanah Sebagai Akibat Penitipan Ganti Kerugian Uang di Pengadilan Negeri dalam Pengadaan Tanah untuk Kepentingan Umum}

Urip Santoso menyatakan bahwa yang dimaksud pelepasan hak atas tanah adalah kegiatan pemutusan hubungan hukum oleh pemegang hak atas tanah dengan hak atas tanah yang dipunyai dengan atau tanpa pemberian ganti kerugian yang layak dan adil kepada pemegang hak atas tanah oleh pihak yang memerlukan tanah, yang berakibat hak atas tanah menjadi hapus dan hak atas tanah kembali menjadi tanah negara atau tanah yang dikuasai langsung oleh Negara (Santoso, 2013).

Abdurrahman memberikan pengertian pelepasan hak adalah perbuatan seseorang pemegang untuk melepaskan apa yang menjadi haknya secara sukarela setelah kepadanya diberikan ganti rugi yang layak (Abdurrahman, 1996).

Pasal 1 angka 9 Undang-Undang No. 2 Tahun 2012 juncto Pasal 1 angka 9 Peraturan Presiden RI Nomor 71 Tahun 2012 sebagaimana diubah yang keempat oleh Pasal 1 angka 9 Peraturan Presiden RI No. 148 Tahun 2015 memberikan pengertian pelepasan hak yaitu kegiatan pemutusan hubungan hukum dari pihak yang berhak kepada negara melalui Lembaga Pertanahan atau Badan Pertanahan Nasional Republik Indonesia. Pelepasan hak atau penyerahan Hak Milik, Hak Guna Usaha, Hak Guna Bangunan, dan Hak Pakai dapat untuk kepentingan umum (kepentingan instansi) atau 
kepentingan perusahaan swasta.

Dengan pelepasan atau penyerahan hak oleh pemegang hak atas tanah berakibat hak atas tanah menjadi hapus dan hak atas tanah kembali menjadi tanah negara atau tanah yang dikuasai langung oleh negara.

\section{a. Diterlantarkan}

Pasal 27 huruf a angka 3 Undang-Undang No. 5 Tahun 1960 (UUPA) menetapkan bahwa Hak Milik hapus karena diterlantarkan oleh pemiliknya. Pasal 34 huruf e Undang-Undang No. 5 Tahun 1960 (UUPA) menetapkan bahwa Hak Guna Usaha hapus karena diterlantarkan. Pasal 40 huruf e Undang-Undang No. 5 Tahun 1960 (UUPA) menetapkan bahwa Hak Guna Bangunan hapus karena diterlantarkan.

Pasal 17 ayat (1) huruf c Peraturan Pemerintah No. 40 Tahun 1996, Pasal 35 ayat (1) huruf c Peraturan Pemerintah No. 40 Tahun 1996, dan Pasal 55 ayat (1) huruf c Peraturan Pemerintah No. 40 Tahun 1996 menetapkan bahwa Hak Guna Usaha, Hak Guna Bangunan, dan Hak Pakai hapus karena diterlantarkan.

Urip Santoso (1996) menyatakan bahwa yang dimaksud dengan tanah diterlantarkan adalah hak atas tanah yang tidak digunakan atau diusahakan sesuai dengan sifat, tujuan, dan keadaannya. Suhariningsih (2009) menyatakan bahwa tanah terlantar dapat diinventarisasi sebagai berikut :

a. tanah tidak dipergunakan sesuai dengan keadaannya atau sifat dan tujuan haknya, bila tanah tersebut tidak dipergunakan sesuai dengan peruntukannya menurut Rencana Tata Ruang Wilayah (RTRW) yang berlaku;

b. tanah yang diterlantarkan oleh pemegang haknya;

c. tidak diusahakan sesuai dengan kriteria pengusahaan tanah pertanian yang baik sesuai ketentuan peraturan perundang-undangan;

d. tanah sengaja tidak dipergunakan oleh pemegang haknya sesuai dengan keadaannya atau sifat dan tujuan haknya.

Peraturan Pemerintah No. 11 Tahun 2010 tentang Penertiban dan Pendayagunaan 
Tanah Terlantar, yang menyatakan tidak berlaku atau mencabut Peraturan Pemerintah No. 36 Tahun 1998 tentang Penertiban dan Pendayagunaan Tanah Terlantar, tidak memberikan pengertian tanah terlantar, akan tetapi menetapkan objek penertiban tanah terlantar sebagaimana diatur dalam Pasal 2 nya yaitu objek penertiban tanah terlantar meliputi tanah yang sudah diberikan hak oleh Negara berupa Hak Milik, Hak Guna Usaha, Hak Guna Bangunan, Hak Pakai, dan Hak Pengelolaan, atau dasar penguasaan atas tanah yang tidak diusahakan, tidak dipergunakan, atau tidak dimanfaatkan sesuai dengan keadaannya atau sifat dan tujuan pemberian hak atau dasar penguasaannya.

Peraturan Pemerintah No. 11 Tahun 2010 dilaksanakan oleh Peraturan Kepala Badan Pertanahan Nasional No. 4 Tahun 2010 tentang Tata Cara Penertiban Tanah Terlantar. Pengertian tanah terlantar dinyatakan dalam Pasal 1 angka 6 Peraturan Kepala Badan Pertanahan Nasional No. 4 Tahun 2010, yaitu tanah yang sudah diberikan hak oleh negara berupa Hak Milik, Hak Guna Usaha, Hak Guna Bangunan, Hak Pakai, dan Hak Pengelolaan, atau dasar penguasaan atas tanah yang tidak diusahakan, tidak dipergunakan, atau tidak dimanfaatkan sesuai dengan keadaan atau sifat dan tujuan pemberian hak atau dasar penguasaannya.

Menteri Agraria dan Tata Ruang/Kepala Badan Pertanahan Nasional RI berwenang menetapkan tanah terlantar dan menerbitkan surat keputusan tentang penelantaran tanah.

Dengan penelantaran tanah oleh pemegang hak atas tanah berakibat hak atas tanah menjadi hapus dan hak atas tanah kembali menjadi tanah negara atau tanah yang dikuasai langsung oleh negara.

\section{b. Pemegang hak tidak memenuhi syarat sebagai subjek hak}

Pasal 27 huruf a angka 4 Undang-Undang No. 5 Tahun 1960 (UUPA) menetapkan bahwa Hak Milik hapus karena ketentuan Pasal 21 ayat (3), yaitu orang asing yang sesudah berlakunya Undang-Undang No. 5 Tahun 1960 (UUPA) memperoleh Hak Milik karena pewarisan tanpa wasiat atau 
percampuran harta karena perkawinan, demikian pula warga negara Indonesia yang mempunyai Hak Milik dan setelah berlakunya Undang-Undang No. 5 Tahun 1960 (UUPA) kehilangan kewarganegaraannya, dan Pasal 26 ayat (2), yaitu jual beli, penukaran, penghibahan, pemberian dengan wasiat, dan perbuatan-perbuatan lain yang dimaksudkan untuk langsung atau tidak langsung memindahkan Hak Milik kepada orang asing, kepada seorang warga negara yang di samping kewaganegaraan Indonesia mempunyai kewarganegaraan asing, atau kepada suatu badan hukum, kecuali yang ditetapkan oleh Pemerintah termaksud dalam Pasal 21 ayat (2). Pasal 34 huruf b Undang-Undang No. 5 Tahun 1960 (UUPA) menetapkan bahwa Hak Guna Usaha hapus karena dihentikan sebelum jangka waktunya berakhir karena sesuatu syarat tidak dipenuhi. Pasal 40 huruf b Undang-Undang No. 5 Tahun 1960 (UUPA) menetapkan bahwa Hak Guna Bangunan hapus karena dihentikan sebelum jangka waktunya berakhir karena sesuatu syarat tidak dipenuhi.
Pasal 17 ayat (1) huruf g Peraturan Pemerintah No. 40 Tahun 1996, Pasal 35 ayat (1) huruf g Peraturan Pemerintah No. 40 Tahun 1996, dan Pasal 55 ayat (1) huruf g Peraturan Pemerintah No. 40 Tahun 1996 menetapkan bahwa Hak Guna Usaha, Hak Guna Bangunan, dan Hak Pakai hapus karena pemegang Hak Guna Usaha, Hak Guna Bangunan, dan Hak Pakai tidak memenuhi syarat sebagai subjek Hak Guna Usaha, Hak Guna Bangunan, dan Hak Pakai.

Pemilik tanah yang berupa orang asing yang memperoleh Hak Milik karena pewarisan tanpa wasiat atau percampuran harta karena perkawinan, perseorangan warga negara Indonesia telah berpindah kewarganegaraan menjadi warga negara asing atau memiliki dwi kewarganegaraan sehingga tidak memenuhi syarat sebagai subjek Hak Milik.

Pemegang Hak Guna Usaha dan Hak Guna Bangunan yang berupa perseorangan warga negara Indonesia telah berpindah kewarganegaraan menjadi warga negara asing sehingga tidak memenuhi syarat sebagai subjek Hak 
Guna Usaha dan Hak Guna Bangunan.

A.P. Parlindungan menyatakan bahwa pemilik tanah dapat kehilangan sama sekali haknya (karena melanggar ketentuan prinsip nasionalitas (Parlindungan, 2008). Yang dimaksud melanggar prinsip nasionalitas adalah pemilik tanah, pemegang Hak Guna Usaha, dan pemegang Hak Guna Bangunan yang semula warga negara Indonesia berpindah kewarganegaraan menjadi warga negara asing.

Pemegang Hak Guna Usaha dan Hak Guna Bangunan yang berupa badan hukum yang didirikan menurut hukum Indonesia dan berkedudukan di Indonesia telah berubah menjadi badan hukum asing sehingga tidak memenuhi syarat sebagai subjek Hak Hak Guna Usaha dan Hak Guna Bangunan.

Tidak terpenuhinya syarat pemilik tanah atau pemegang Hak Guna Usaha, Hak Guna Bangunan, dan Hak Pakai sebagai subjek hak yang menjadi penyebab hapusnya Hak Milik, Hak Guna Usaha, Hak Guna Bangunan, dan Hak Pakai.

\section{c. Berakhirnya jangka waktu hak}

Pasal 34 huruf a Undang-Undang No. 5 Tahun 1960 (UUPA) menetapkan bahwa Hak Guna Usaha hapus karena jangka waktunya berakhir. Pasal 40 huruf a Undang-Undang No. 5 Tahun 1960 (UUPA) menetapkan bahwa Hak Guna Bangunan hapus karena jangka waktunya berakhir.

Pasal 17 ayat (1) huruf a Peraturan Pemerintah No. 40 Tahun 1996, Pasal 35 ayat (1) huruf a Peraturan Pemerintah No. 40 Tahun 1996, dan Pasal 55 ayat (1) huruf a Peraturan Pemerintah No. 40 Tahun 1996 menetapkan bahwa Hak Guna Usaha, Hak Guna Bangunan, dan Hak Pakai hapus karena berakhirnya jangka waktu sebagaimana ditetapkan dalam keputusan pemberian atau perpanjangannya.

Hak Guna Usaha, Hak Guna Bangunan atas tanah negara, Hak Guna Bangunan atas tanah Hak Pengelolaan, Hak Pakai atas tanah negara, dan Hak Pakai atas tanah Hak Pengelolaan berakhir jangka waktunya, akan tetapi tidak diajukan perpanjangan jangka waktunya oleh 
pemegang haknya.

Hak Guna Usaha, Hak Guna Bangunan atas tanah negara, Hak Guna Bangunan atas tanah Hak Pengelolaan, Hak Pakai atas tanah negara, dan Hak Pakai atas tanah Hak Pengelolaan berakhir perpanjangan jangka waktunya, akan tetapi tidak diajukan pembaharuan hak oleh pemegang haknya.

Hak Guna Bangunan atas tanah Hak Milik, Hak Pakai atas tanah Hak Milik berakhir jangka waktunya, akan tetapi tidak diajukan pembaharuan hak oleh pemegang Hak Guna Bangunan atau pemegang Hak Pakai.

\section{d. Dibatalkan oleh pejabat yang berwenang}

Pasal 17 ayat (1) huruf b Peraturan Pemerintah No. 40 Tahun 1996 menetapkan bahwa Hak Guna Usaha hapus karena dibatalkan oleh pejabat yang berwenang sebelum jangka waktunya berakhir. Pasal 35 ayat (1) huruf b Peraturan Pemerintah No. 40 Tahun 1996 dan Pasal 55 ayat (1) huruf b Peraturan Pemerintah No. 40 Tahun 1996 menetapkan bahwa Hak Guna Bangunan dan Hak Pakai hapus karena dibatalkan oleh pejabat yang berwenang, pemegang Hak Pengelolaan atau pemegang Hak Milik sebelum jangka waktunya berakhir. Hak Guna Usaha dibatalkan oleh pejabat yang berwenang sebelum jangka waktunya berakhir karena :

a) tidak dipenuhinya kewajiban-kewajiban pemegang Hak Guna Usaha dan/atau dilanggarnya ketentuan-ketentuan sebagaimana dimaksud dalam Pasal 12, Pasal 13, dan Pasal 14.

b) putusan pengadilan yang telah mempunyai kekuatan hukum tetap.

Hak Guna Bangunan dan Hak Pakai dibatalkan oleh pejabat yang berwenang, pemegang Hak Pengelolaan atau pemegang Hak Milik sebelum jangka waktunya berakhir karena :

a) tidak dipenuhinya kewajiban-kewajiban pemegang Hak Guna Bangunan dan/atau dilanggarnya ketentuan-ketentuan sebagaimana dimaksud dalam Pasal 30, Pasal 31, dan Pasal 32 untuk Hak Guna Bangunan. Pasal 50, 
Pasal 51, dan Pasal 52 untuk Hak Pakai.

b) tidak dipenuhinya syarat-syarat atau kewajiban-kewajiban yang tertuang dalam perjanjian pemberian Hak Guna Bangunan dan Hak Pakai antara pemegang Hak Guna Bangunan dan Hak Pakai dengan pemegang Hak Milik, atau perjanjian penggunaan tanah Hak Pengelolaan;

c) putusan pengadilan yang telah mempunyai kekuatan hukum tetap.

Berdasarkan Peraturan Menteri Negara Agraria/Kepala Badan Pertanahan Nasional No. 9 Tahun 1999, pejabat yang berwenang membatalkan Hak Milik, Hak Guna Usaha, Hak Guna Bangunan, dan Hak Pakai adalah Kepala Badan Pertanahan Nasional Republik Indonesia.

\section{e. Tanahnya musnah}

Hak Milik, Hak Guna Usaha, Hak Guna Bangunan, dan Hak Pakai musnah disebabkan oleh bencana alam, misalnya tanah longsor, gempa bumi, sunami, kerusuhan, tanah di tepi pantai yang terkena abrasi air laut, tanah di tepi sungai yang longsor karena meluapnya air sungai, atau pergeseran tanah (likuifaksi).

Hapusnya Hak Milik, Hak Guna Usaha, Hak Guna Bangunan, dan Hak Pakai disebabkan oleh :

a. Perbuatan hukum. Perbuatan hukum yang berakibat hapusnya Hak Milik, Hak Guna Usaha, Hak Guna Bangunan, dan Hak Pakai, adalah : pelepasan hak atau penyerahan hak; penelantaran tanah; pemegang Hak Guna Usaha, Hak Guna Bangunan, dan Hak Pakai tidak memperpanjang jangka waktu atau memperbaharui hak atas tanahnya; perubahan kewarganegaraan pemegang hak atau perubahan badan hukum.

b. Peristiwa hokum. Peristiwa hukum yang berakibat hapusnya Hak Milik, Hak Guna Usaha, Hak Guna Bangunan, dan Hak Pakai, adalah tanahnya musnah.

c. Penetapan Pemerintah. Penetapan Pemerintah yang berakibat hapusnya Hak Milik, Hak Guna Usaha, Hak Guna Bangunan, dan Hak Pakai, adalah : a) Keputusan Presiden tentang pencabutan hak atas tanah untuk 
kepentingan umum; b) Keputusan Kepala Badan Pertanahan Nasional Republik Indonesia tentang pembatalan hak atas tanah disebabkan oleh tidak dipenuhinya kewajiban-kewajiban oleh pemegang hak atas tanah atau melaksanakan putusan pengadilan yang telah mempunyai kekuatan hukum tetap.

Akibat hukum hapusnya Hak Milik, Hak Guna Usaha, Hak Guna Bangunan, dan Hak Pakai tidak selalu tanahnya kembali menjadi tanah negara atau tanah yang dikuasai langsung oleh negara, bergantung pada asal hak atas tanahnya, yaitu asal tanahnya adalah tanah negara, tanah Hak Pengelolaan, ataukah Hak Milik. Kalau hak atas tanah berasal dari tanah negara, maka hapusnya hak atas tanah berakibat tanah kembali menjadi tanah negara atau tanah yang dikuasai langsung oleh negara. Kalau hak atas tanah berasal dari tanah Hak Pengelolaan, maka hapusnya hak atas tanah berakibat tanah kembali ke dalam penguasaan pemegang Hak Pengelolaan. Kalau hak atas tanah berasal dari tanah Hak Milik, maka hapusnya hak atas tanah berakibat tanah kembali ke dalam penguasaan pemegang Hak Milik.

Hak atas tanah dapat hapus disebabkan penitipan ganti kerugian uang di Pengadilan Negeri dalam pengadaan tanah untuk kepentingan umum, sebagaimana ditetapkan dalam Pasal 43 Undang-Undang No. 2 Tahun 2012. Faktor penyebab penitipan ganti kerugian uang di Pengadilan Negeri dalam pengadaan tanah untuk kepentingan umum, adalah dalam hal pihak yang berhak atas ganti kerugian menolak bentuk dan/atau besarnya ganti kerugian berdasarkan hasil musyawarah dengan Pelaksana Pengadaan Tanah (PPT), putusan Pengadilan Negeri/Mahkamah Agung yang telah memperoleh kekuatan hukum tetap, pihak yang berhak menerima ganti kerugian tidak diketahui keberadaannya, objek pengadaan tanah yang akan diberikan ganti kerugian sedang menjadi objek perkara di pengadilan, objek pengadaan tanah yang akan diberikan ganti kerugian masih dipersengketakan kepemilikannya, objek pengadaan tanah yang akan diberikan 
ganti kerugian diletakkan sita oleh pejabat yang berwenang; atau objek pengadaan tanah yang akan diberikan ganti kerugian menjadi jaminan di bank.

Dengan hapusnya hak atas tanah yang disebabkan oleh penitipan ganti kerugian uang di Pengadilan Negeri dalam pengadaan tanah untuk kepentingan umum berakibat hak atas tanah kembali menjadi tanah negara atau tanah yang dikuasai langsung oleh negara. Dengan penitipan ganti kerugian uang di Pengadilan Negeri dalam pengadaan tanah untuk kepentingan umum membuat pemegang hak atas tanah tidak lagi memiliki atau menguasai hak atas tanahnya meskipun pemegang hak atas tanah belum mendapatkan ganti kerugian dari instansi yang memerlukan tanah.

Pasal 27 Undang-Undang No. 5 Tahun 1960 (UUPA) menetapkan hapusnya Hak Milik karena pencabutan hak atas tanah, penyerahan dengan sukarela oleh pemiliknya, diterlantarkan, pemiliknya tidak memenuhi syarat sebagai subjek Hak Milik, dan tanahnya musnah.

Pasal 34 Undang-Undang No. 5 Tahun
1960 (UUPA) menetapkan hapusnya Hak Guna Usaha karena jangka waktunya berakhir, dihentikan sebelum jangka waktunya berakhir karena sesuatu yang tidak dipenuhi, dilepaskan oleh pemegang haknya sebelum jangka waktunya berakhir, dicabut untuk kepentingan umum, diterlantarkan, tanahnya musnah, atau pemegang haknya tidak memenuhi syarat sebagai subjek Hak Guna Usaha.

Pasal 40 Undang-Undang No. 5 Tahun 1960 (UUPA) menetapkan hapusnya Hak Guna Bangunan karena jangka waktunya berakhir, dihentikan sebelum jangka waktunya berakhir karena sesuatu yang tidak dipenuhi, dilepaskan oleh pemegang haknya sebelum jangka waktunya berakhir, dicabut untuk kepentingan umum, diterlantarkan, tanahnya musnah, atau pemegang haknya tidak memenuhi syarat sebagai subjek Hak Guna Bangunan.

Peraturan Pemerintah No. 40 Tahun 1996 menetapkan bahwa Hak Guna Usaha, Hak Guna Bangunan, dan Hak Pakai hapus karena tidak dipenuhinya syarat-syarat atau kewajiban-kewajiban oleh pemegang Hak Guna Usaha, Hak Guna Bangunan 
dan Hak Pakai, atau melaksanakan putusan pengadilan yang telah mempunyai kekuatan hukum tetap.

Hak Milik dapat hapus karena tidak dipenuhinya syarat-syarat atau kewajiban-kewajiban oleh pemilik tanah, atau melaksanakan putusan pengadilan yang telah mempunyai kekuatan hukum tetap.

Hak atas tanah dapat hapus disebabkan penitipan ganti kerugian uang di Pengadilan Negeri dalam pengadaan tanah untuk kepentingan umum sebagaimana ditetapkan dalam Pasal 43 Undang-Undang No. 2 Tahun 2012 menciptakan hapusnya hak atas tanah yang baru di luar yang ditetapkan oleh Undang-Undang No. 5 Tahun 1960 (UUPA).

Secara teoritik, hapusnya hak atas tanah dapat terjadi karena pertama, perbuatan hukum, yaitu pemegang hak melakukan pelepasan hak atau penyerahan hak; penelantaran tanah; pemegang Hak Guna Usaha, Hak Guna Bangunan, dan Hak Pakai tidak memperpanjang jangka waktu atau memperbaharui hak atas tanahnya; perubahan kewarganegaraan pemegang hak atau perubahan badan hukum. Kedua, peristiwa hukum, yaitu tanahnya musnah. Ketiga, penetapan Pemerintah, yaitu Keputusan Presiden tentang pencabutan hak atas tanah untuk kepentingan umum, Keputusan Kepala Badan Pertanahan Nasional Republik Indonesia tentang pembatalan hak atas tanah disebabkan oleh cacat hukum administrasi atau melaksanakan putusan pengadilan yang telah mempunyai kekuatan hukum tetap.

Dalam hapusnya hak atas tanah yang disebabkan oleh penitipan ganti kerugian uang di Pengadilan Negeri dalam pengadaan tanah untuk kepentingan umum tidak ada perbuatan hukum yang berupa pelanggaran hukum atau tidak dipenuhinya kewajiban hukum yang dilakukan oleh pemegang hak atas tanah, yang dapat berakibat hak atas tanah menjadi hapus.

Bentuk hapusnya hak atas tanah yang disebabkan tidak adanya pelanggaran hukum atau tidak dipenuhinya kewajiban hukum oleh pemegang hak atas tanah, untuk kepentingan umum, dan ada 
pemberian ganti kerugian kepada pemegang hak atas tanah adalah pencabutan hak atas tanah oleh Presiden. Hapusnya hak atas tanah yang disebabkan oleh penitipan ganti kerugian uang di Pengadilan Negeri dalam pengadaan tanah untuk kepentingan umum tidak ada pelanggaran hukum atau tidak dipenuhinya kewajiban hukum oleh pemegang hak atas tanah, untuk kepentingan umum, dan ada pemberian ganti kerugian kepada pemegang hak atas tanah.

Ada kesamaan antara hapusnya hak atas tanah yang disebabkan oleh pencabutan hak atas tanah oleh Presiden dan penitipan ganti kerugian uang di Pengadilan Negeri dalam pengadaan tanah untuk kepentingan umum, yaitu tidak ada pelanggaran hukum atau tidak dipenuhinya kewajiban hukum oleh pemegang hak atas tanah, untuk kepentingan umum, dan ada pemberian ganti kerugian kepada pemegang hak atas tanah. Dengan demikian, penitipan ganti kerugian uang di Pengadilan Negeri dalam pengadaan tanah untuk kepentingan umum merupakan pencabutan hak atas tanah secara terselubung oleh instansi yang memerlukan tanah.

\section{PENUTUP}

1. Untuk menjamin kepastian hukum, setiap bidang hak atas tanah di seluruh wilayah Republik Indonesia didaftar oleh Kantor Pertanahan Kabupaten/Kota atau didaftarkan oleh pemegang hak atas tanah. Pendaftaran tanah dapat dilakukan melalui pendaftaran tanah secara sistematik dan pendaftaran tanah secara sporadik. Pendaftaran tanah menghasilkan surat tanda bukti hak yang dinamakan sertipikat, yang diterbitkan oleh Kantor Pertanahan Kabupaten/Kota. Sertipikat hak memuat data fisik dan data yuridis yang merupakan Salinan dari buku tanah dan surat ukur. Dengan diterbitkan sertipikat hak, maka jaminan kepastian hukum, yang meliputi kepastian status hak, kepastian subjek hak, dan kepastian objek. Sertipikat hak mempunyai sifat pembuktian yang kuat, yaitu data fisik dan data yuridis yang dimuat dalam 
sertipikat dinyatakan benar sepanjang tidak dibuktikan sebaliknya dengan alat bukti yang lain. Pasal 43 Undang-Undang No. 2 Tahun 2012 menetapkan bahwa dengan penitipan ganti kerugian uang di Pengadilan Negeri dalam pengadaan tanah untuk kepentingan umum berakibat alat bukti hak atas tanah (sertipikat hak) dinyatakan tidak berlaku. Dengan tidak berlakunya sertipikat hak sebagai akibat penitipan ganti kerugian uang di Pengadilan Negeri dalam pengadaan tanah untuk kepentingan umum membawa konsekuensi sertipikat hak menjadi batal atau tidak sah. Batal atau tidak sahnya sertipikat hak ini bertentangan dengan asas contrarius actus, yaitu batalnya sebuah keputusan harus dilakukan oleh pejabat yang menerbitkan keputusan tersebut. Sertipikat hak sebagai Keputusan Tata Usaha Negara (KTUN) diterbitkan oleh oleh Kantor Pertanahan Kabupaten/Kota, maka pembatalan sertipikat hak dilakukan oleh Kepala
Badan Pertanahan Nasional Republik Indonesia dengan Surat Keputusan Pembatalan Sertipikat Hak;

2. Hak atas tanah yang dimiliki atau dikuasai oleh seseorang tidak selalu untuk selama-lamanya, akan hak atas tanah itu dapat hapus. Hapusnya hak atas tanah dapat terjadi disebabkan oleh 3 (tiga) hal, yaitu pertama, hak atas tanah hapus karena perbuatan hukum, yaitu pemegang hak atas tanah melepaskan atau menyerahkan hak atas tanahnya untuk kepentingan pihak lain, pemegang hak atas tanah menelantarkan hak atas tanahnya, pemegang hak atas tanah tidak memperpanjang jangka waktu atau memperbaharui hak atas tanahnya, pemegang hak atas tanah berpindah kewarganegaraan menjadi warga negara asing, Kedua, hak atas tanah hapus karena peristiwa hukum, yaitu tanahnya musnah, dan ketiga, hak atas tanah hapus karena penetapan Pemerintah, yaitu dicabut untuk kepentingan umum oleh Presiden Republik Indonesia atau 
dibatalkan oleh Kepala Badan Pertanahan Nasional Republik

Indonesia. Akibat hukum hapusnya Hak Milik, Hak Guna Usaha, Hak Guna Bangunan, dan Hak Pakai tidak selalu tanahnya kembali menjadi tanah negara atau tanah yang dikuasai langsung oleh negara, bergantung pada asal hak atas tanahnya, yaitu asal tanahnya adalah tanah negara, tanah Hak Pengelolaan, ataukah Hak Milik. Pasal 43 Undang-Undang No.

2 Tahun 2012 menetapkan bahwa dengan penitipan ganti kerugian uang di Pengadilan Negeri dalam pengadaan tanah untuk kepentingan umum berakibat hak atas tanah menjadi hapus dan tanahnya kembali menjadi tanah negara atau tanah yang dikuasai langsung oleh negara. Undang-Undang No. 2 Tahun 2012 menciptakan hapusnya hak atas tanah baru, yang tidak sesuai dengan Undang-Undang No. 5 Tahun 1960 (UUPA). Hapusnya hak atas tanah karena penitipan ganti kerugian uang di Pengadilan Negeri dalam pengadaan tanah untuk kepentingan umum ini tidak ada pelanggaran atau kewajiban yang tidak dipenuhi oleh pemegang hak atas tanah sehingga hapusnya hak atas tanah karena penitipan ganti kerugian dapat disamakan dengan hapusnya hak atas tanah karena pencabutan hak atas tanah.

\section{DAFTAR PUSTAKA}

Abdurrahman, Masalah-masalah Pencabutan Hak-hak Atas Tanah dan Pengadaan Tanah Bagi Pelaksanaan Pembangunan Untuk Kepentingan Umum di Indonesia, Citra Aditya Bakti, Bandung, 1996, h. 6,26 .

A.P. Parlindungan, Berakhirnya Hak-hak Atas Tanah Menurut Sistem Undang-Undang Pokok Agraria, Mandar Maju, Bandung,2008, h. 1.

Harsono, Boedi, Hukum Agraria Indonesia Sejarah Pembentukan Undang-Undang Pokok Agraria, Isi, dan Pelaksanaannya, Djambatan, Jakarta, 2003. h. 480.

Maria S.W. Sumardjono, Dinamika Pengaturan Pengadaan Tanah di Indonesua Dari Keputusan Presiden Sampai Undang-Undang, Gadjah Mada University Press. Yogyakarta, 2015, h. 3.

Philipus M Hadjon dan Tatiek Sri Djatmiati, Argumentasi Hukum, 
Gadjah Mada University Press, Yogyakarta, 2016, h. 83.

Saifudin Noorhadi, Disertasi, Program Pascasarjana, Universitas Brawijaya, Malang, 2005, h. 63.

Sri Mamuji, Penelitian Hukum Normatif, Rajawali Press, Jakarta, 1990, h. 14.

Suhariningsih, Tanah Terlantar Asas dan Pembaharuan Konsep Menuju Penertiban, Pustaka Prestasi, Jakarta, Agustus 2009.

Suyanto \& Arif, Muhammad Fuad, Status Sertifikat Tanah Hak Milik Ganda Menurut Peraturan Pemerintah Nomor 24 Tahun 1997 Tentang Pendaftaran Tanah (Studi Kasus Nomor: 629/Pdt.G/2012/PN.Sby), Jurnal Pro Hukum Vol 6 No.1 Tahun 2017. Diakses di http://journal.unigres.ac.id/index.p hp/JurnalProHukum/article/view/4 70

Urip Santoso (selanjutnya disebut Urip Santoso - I), Hukum Pengadaan Tanah Untuk Kepentingan Umum, Airlangga University Press, Surabaya, 2013, h. 7,29

Urip Santoso (selanjutnya disebut Urip Santoso - II), Buku Ajar Hukum Pengadaan Tanah dan Pendaftaran Hak Atas Tanah, Revka Petra Media, Surabaya, 2018, h. 21. 